\title{
REVISION OF THE GENUS CETRELIA (LECANORALES, ASCOMYCOTA) IN THE BIAŁOWIEŻA FOREST (BELARUSSIAN PART)
}

\author{
Vladimir Golubkov, Anna Matwiejuk, Pavel Bely, Andrei Tsurykau
}

\begin{abstract}
V.Ya. Golubkov, Department of Botany, Faculty of Biology and Ecology, Kupala Hrodna State University, Azheshka Str. 22, BY-230023 Hrodna, Belarus, e-mail: vgolubkov@tut.by, vgolubkov@tut.by

A. Matwiejuk, Department of Botany, Institute of Biology, University in Białystok, Konstantego Ciołkowskiego 1 J, 15-245 Białystok, Poland, e-mail: matwiej@uwb.edu.pl

P. Bely, Laboratory of Ecological Physiology of Plants, Central Botanical Garden of the National Academy of Sciences of the Republic of Belarus, Surganova Str. 2 B, BY-220012 Minsk, Belarus, e-mail: pavel.bely@ tut.by

A.F. Tsurykau, Department of Biology, Skorina Gomel State University, Sovetskaja Str. 104, BY-246019 Gomel, Belarus, e-mail: tsurikov@front.ru
\end{abstract}

(Received: April 8, 2015. Accepted: June 15, 2015)

\begin{abstract}
AвSTRACT. In the territory of NP the Białowieża Forest no special research on specific structure of lichens of the Cetrelia has been carried out, and there are only single instructions in publications (GoluBKOv 1986, 1987 and others) whose definitions are based on morphological characteristics and results of colour chemical reactions which are not always reliable. Three taxa of Cetrelia (C. cetrarioides, C. monachorum, C. olivetorum) have been identified in a study of the genus in Belarussian part of the Białowieża Forest. Cetrelia monachorum is the commonest member of the genus in the Białowieża Forest (46 records), whereas C. olivetorum is known from 35 localities. Cetrelia cetrarioides appears to be the rarest species of the genus in the Białowieża Forest (2 records). The distribution and status of three species in the Białowieża Forest are reviewed, distribution maps are provided, and the merits of the segregates for conservation measures are discussed.
\end{abstract}

KeY wORDs: cetrarioid lichens, biodiversity, Białowieża Forest, Belarus

\section{INTRODUCTION}

The genus Cetrelia W.L. Culb. \& C.F. Culb. is characterised by its foliose, loosely attached grey thallus with laminal pseudocyphellae, prosoplectenchymatous upper cortex, at least partly black lower cortex with sparse rhizines, marginal pycnidia, ellipsoid ascospores and atranorin as the main cortical secondary metabolite. The species produce several depsidones as diagnostic medullary substances (CULBERSON \& Culberson 1968, Randlane \& SaAg 1991, Obermayer \& MAYRHOFer 2007).

Currently, 18 Cetrelia species are known worldwide, with the greatest species diversity in eastern and southeastern Asia (Culberson \& Culberson 1968, 1976, RANDLANE \& SAAG 1991, 2004, OtNYUKova et al. 2009, Urbanavichus \& Andreev 2010). In Europe, only four taxa have been reported: Cetrelia cetrarioides (Duby) W.L. Culb. \& C.F. Culb., C. chicitae
(W.L. Culb.) W.L. Culb. \& C.F. Culb., C. monachorum (Zahlbr.) W.L. Culb. \& C.F. Culb. and C. olivetorum (Nyl.) W.L. Culb. \& C.F. Culb. (Culberson \& CulBerson 1968, 1976, Obermayer \& MaYrhofer 2007, Feuerer 2010, Kukwa \& Motiejūnaite 2012, Kukwa et al. 2012). These species of Cetrelia represent the sorediate cetrarioides-morphotype (RANDLANE \& SAAG 2004). The sorediate taxa (C. chicitae, C. cetrarioides, $C$. monachorum, $C$. olivetorum) are most widespread and occur on two continents, Eurasia and North America. Additionally, Cetrelia olivetorum has been reported from South America (Argentina) and Australia. These species differ mainly by the secondary chemistry, however also some thallus characters can be used to separate them (e.g. Obermayer \& MAYrhofer 2007).

In Belarus, usually three species were recognised, Cetrelia cetrarioides (GolubKov 1986, 2011, Bely 2011), C. monachorum (HAwKsworth et al. 2008, Bely 2011) and C. olivetorum (Hawksworth et al. 2008, BelY 
2011). As the specimens of the genus Cetrelia have never been studied with the aid of thin layer chromatography (TLC) in Belarus (only spot test reaction with $\mathrm{C}$ and microcrystal tests was performed), the number of species, as well as their status on protected areas of Belarus have remained unknown. In this paper, we present the results of the studies of the genus Cetrelia in the Białowieża Forest in Belarus, with notes on the chemistry, morphology and habitat requirements.

The Polish part of the Białowieża Forest, four species of the genus (Cetrelia chicitae, C. cetrarioides, C. monachorum, C. olivetorum) were reported (KuKwa et al. 2012).

\section{STUDY AREA}

The Białowieża Forest is the oldest national park of Europe situated in Western part of Belarus within Grodno and Brest provinces (70 km away from Brest and $30 \mathrm{~km}$ away from Kamenets) along the state border with Poland and partially on the territory of Poland (Fig. 1).

Thanks to several ages of protection the Forest has survived in its natural state to this day. The Białowieża National Park (Poland) was inscribed on the World Heritage List in 1979 and extended to include Belovezhskaya Pushcha (Belarus) in 1992. A large extension of the property of Belarussian and Polish parts of the Białowieża Forest in 2014 results in a property of 141,885 ha with a buffer zone of 166,708 ha. Nowadays the Belorussian part of the national park is subdivided into transition, buffer and core zones and occupies the area of 216,200 ha (Decisions... 2014, KravchuK 2015).

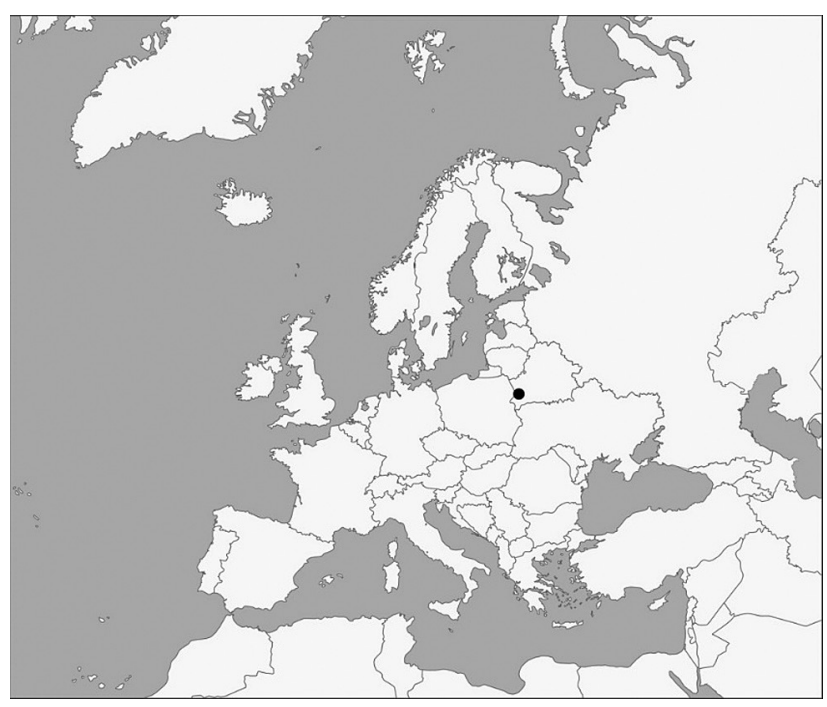

Fig. 1. Location of study area

\section{MATERIAL AND METHODS}

The study is based on the samples collected mainly by V.V. Golubkov on the territory of the Belarusian part of the Białowieża Forest National Park in 1983-1984.

During that period large hurricanes passed through the territory of the Białowieża Forest. As a result, a lot of Cetrelia samples were collected from fallen trunks of trees. All the specimens are housed in Herbarium of the Grodno State University by Yanka Kupala (GRSU), V.F. Kuprevich Institute of Experimental Botany Herbarium of the National Academy of Scientific and Practical Center on Bioresources (MSK) and Herbarium of Introduced Plants of the Central Botanical Gardens of the National Academy of Scientific of Belarus (MSKH).

The morphology was examined under a stereo microscope for thallus colour, and the shape and size of pseudocyphellae and soralia. Chemistry of samples was studied by A. Matwiejuk, A. Tsurykau and P. Bely. Lichen substances were investigated by thin layer chromatography (TLC) in solvent systems A and $\mathrm{C}$ following the methods described by CulBerson \& Kristinsson (1970) and Orange et al. (2001). Additionally, spot test reaction with C (commercial bleach) was applied separately or in combination with $\mathrm{K}$ (solution of $10 \%$ potassium hydroxide, KC test).

Names of Belarusian vegetation types are followed by Yurkevich et al. (1977). The names and descriptions of forest communities are shown in Table 1.

\section{RESULTS AND DISCUSSION}

The revision of all available specimens has shown that the genus Cetrelia in the Białowieża Forest in Belarus is represented by three species: C. cetrarioides, C. monachorum and C. olivetorum. Cetrelia monachorum is the commonest one in the Białowieża Forest. Some specimens of the species were found in a collection of $C$. cetrarioides, as both taxa have similar spot reactions with $\mathrm{C}$ and $\mathrm{KC}$. On the other hand, most specimens of $C$. olivetorum have been correctly identified as the only taxon with distinctive $\mathrm{C}+$ reaction.

\section{CETRELIA CETRARIOIDES (DELISE) W.L. CULB. \& C.F. CULB.}

In: Contrib. U.S. Natl. Herb. 34: 498. 1968. = Parmelia cetrarioides Delise, in Duby, Bot. Gall. (Paris) 2(2): 601.1830.

Diagnostic characters. Pseudocyphellae on the upper surface small to rather large, almost always not raised, and those on the lower surface of the lobes well developed (at least on ascending, contorted lobes), but sometimes lacking. Soralia often very smooth and strongly convex. Soredia small (usually up to $35 \mu \mathrm{m}$ ). Chemically C. cetrarioides is char- 
Table 1. List of Belarusian vegetation types

\begin{tabular}{|c|c|c|c|}
\hline $\begin{array}{l}\text { Description } \\
\text { (Categories) }\end{array}$ & Belarusian scientific name & European scientific name & Description of forest types \\
\hline \multirow[t]{5}{*}{ Hemiboreal forest } & Pinetum myrtillosum & mixed Scots pine-birch forest & \multirow{5}{*}{$\begin{array}{l}\text { The type is characterised by mixtures of Pinus } \\
\text { sylvestris and Picea abies with broadleaves } \\
\text { deciduous trees such as Betula spp., Populus } \\
\text { tremula, Alnus spp. and Sorbus aucuparia. The } \\
\text { broadleaved trees generally characterise } \\
\text { early-to-mid-successional stages; with age the } \\
\text { dominance of coniferous species increases. }\end{array}$} \\
\hline & Pinetum oxalidosum & mixed Scots pine-birch forest & \\
\hline & Piceetum oxalidosum & hemiboreal spruce forest & \\
\hline & Piceetum polytrichosum & hemiboreal spruce forest & \\
\hline & Piceetum filicosum & hemiboreal spruce forest & \\
\hline \multirow[t]{5}{*}{$\begin{array}{l}\text { Mesophytic deciduous } \\
\text { forest }\end{array}$} & Aceretum oxalidosum & maple-oak forest & $\begin{array}{l}\text { Forests dominated by Acer platanoides and } \\
\text { Quercus robur. }\end{array}$ \\
\hline & Carpinetum oxalidosum & oak-hornbeam forest & \multirow[t]{2}{*}{$\begin{array}{l}\text { Forests dominated by hornbeam (Carpinus } \\
\text { betulus) and Quercus robur. }\end{array}$} \\
\hline & Carpinetum myrtillosum & oak-hornbeam forest & \\
\hline & Quercetum oxalidosum & $\begin{array}{l}\text { pedunculated oak-hornbeam } \\
\text { forest }+ \text { sessile oak-horn- }\end{array}$ & \multirow{2}{*}{$\begin{array}{l}\text { Forests dominated by Quercus robur or Q. pe- } \\
\text { traea and hornbeam (Carpinus betulus). On wet } \\
\text { soils, Quercus robur dominates, on dry soils } \\
\text { Q. petraea prevails. }\end{array}$} \\
\hline & Quercetum filicosum & beam forest & \\
\hline \multirow[t]{2}{*}{$\begin{array}{l}\text { Moist broadleaved } \\
\text { forests }\end{array}$} & Fraxinetum aegopodiosum & ashwood and oak-ash forest & $\begin{array}{l}\text { Forests dominated by Fraxinus excelsior grow- } \\
\text { ing in basic and moist soils. }\end{array}$ \\
\hline & Quercetum subalveto-fluviatilis & $\begin{array}{l}\text { pedunculated oak-hornbeam } \\
\text { forest }\end{array}$ & $\begin{array}{l}\text { Forests on soils with high water-tables but } \\
\text { rarely flooded. Typically the tree layer is dom- } \\
\text { inated by pedunculated oak (Quercus robur), } \\
\text { with ample presence of aspen, birch, and } \\
\text { partly black alder. }\end{array}$ \\
\hline \multirow[t]{8}{*}{ Mire and swamp forest } & Betuletum caricosum & birch swamp forest & $\begin{array}{l}\text { Forests dominated by Betula pubescens often } \\
\text { mixed with conifer trees, Salix sp. and Alnus } \\
\text { glutinosa. }\end{array}$ \\
\hline & Glutinoso-alnetum caricosum & black alder swamp forest & \multirow{5}{*}{$\begin{array}{l}\text { Forests dominated by black alder. Typical for } \\
\text { such forests is that the ground at the time } \\
\text { for snow melting and during rainy periods } \\
\text { is covered by water, or that the soils become } \\
\text { wet throughout for a period. In old alder } \\
\text { forests tussocks are created, where the trees } \\
\text { are standing. This is caused as an effect of } \\
\text { the growing system of the tree, because new } \\
\text { shoots are frequently created from the base of } \\
\text { the original stem. }\end{array}$} \\
\hline & Glutinoso-alnetum utricosum & black alder swamp forest & \\
\hline & Glutinoso-alnetum aegopodiosum & black alder swamp forest & \\
\hline & Glutinoso-alnetum oxalidosum & black alder swamp forest & \\
\hline & Glutinoso-alnetum thelipteriosum & black alder swamp forest & \\
\hline & Piceetum caricosum & $\begin{array}{l}\text { conifer dominated or mixed } \\
\text { mire forest }\end{array}$ & \multirow{2}{*}{$\begin{array}{l}\text { Spruce (Picea abies) birch (Betula pubescens) } \\
\text { swamps are mainly restricted to depressions } \\
\text { in the terrain and often fringe larger mires. }\end{array}$} \\
\hline & Piceetum fontinale-herbosum & $\begin{array}{l}\text { conifer dominated or mixed } \\
\text { mire forest }\end{array}$ & \\
\hline
\end{tabular}

acterised by the producing of atranorin, perlatolic, 4-O-methylolivetoric and anziaic acids. Imbricaric acid always occurs in minor amounts.

Notes. Cetrelia cetrarioides can be easily distinguished from the other members of the genus by its smooth convex soralia, small soredia, and presence of pseudocyphellae on the lower side of sterile, ascending and contorted lobes. See also notes under C. monachorum.

Habitat requirements. Cetrelia cetrarioides has been collected on Alnus glutinosa (1 specimen) and Juniperus communis (1). In Poland, in the Białowieża Forest Cetrelia cetrarioides was collected from Carpinus betulus (1 specimens) and Picea abies (1) (Kukwa et al. 2012). It is not possible to discuss the ecology of C. cetrarioides in the Belarusian part of the Białowieża Forest as only two localities are known.
Distribution in the Białowieża Forest. In the Belovezhskaya Puscha National Park (Belarus) C. cetrarioides was found only twice (Fig. 2). The species is also known from the Polish part of the Białowieża National Park by the reference to the middle of the twentieth century (KUKWA et al. 2012).

General distribution. The species is rather widely distributed. In Europe C. cetrarioides has been reported from Austria, Bulgaria, Czech Republic, Estonia, Finland, France, Germany, Hungary, Italy, Luxembourg, Montenegro, Norway, Poland, Portugal, Romania, Russia, Serbia, Slovakia, Slovenia, Spain, Sweden, Switzerland, Ukraine and United Kingdom (Hawksworth et al. 2008, 2011, KuKwa et al. 2012). Outside Europe it has been recorded from Armenia, Azerbaijan Republic, Bhutan, Chile, China, Georgia, Hawaiian Islands, Iran, Japan, Mexico, Rus- 


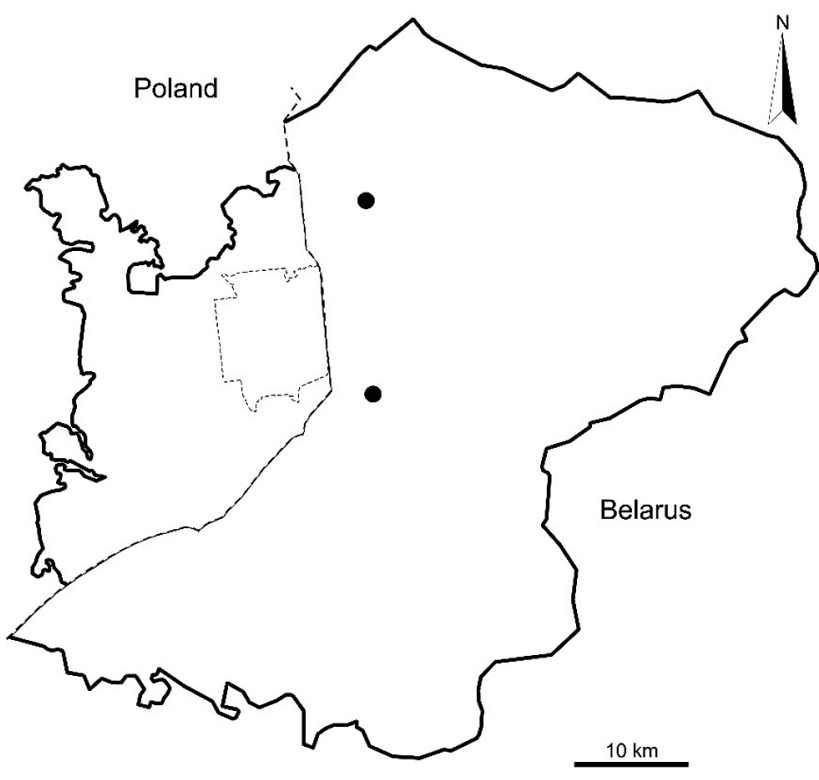

Fig. 2. Distribution of Cetrelia cetrarioides in the Białowieża Forest

sia (Asiatic part), USA and Western Samoa (Culberson \& Culberson 1968, 1976, Randlane \& SaAg 1991, 2004, Aptroot \& Feijen 2002, Kurokava 2003, Lai et al. 2009).

Specimens examined. Brest region. Pruzhany district, Khvoinik forestry, forest comp. No 434, $52^{\circ} 43^{\prime} \mathrm{N} / 23^{\circ} 59^{\prime} \mathrm{E}$, Fraxinetum aegopodiosum, on Alnus glutinosa, 13.07.1984; Grodno region: Svisloch district, Brovsk forestry, forest comp. No 103, $52^{\circ} 51^{\prime} \mathrm{N} / 23^{\circ} 57^{\prime} \mathrm{E}$, Pinetum myrtillosum, on Juniperus communis, 25.09.1984.

\section{CETRELIA MONACHORUM (ZAHLBR.) W.L. CULB. \& C.F. CULB.}

In: C.F. Culb. \& W.L. Culb. Syst. Bot. 1(4): 326.1977 [1976]. = Parmelia monachorum Zahlbr., in Handel-Mazzetti, Symb. Sin. 3: 180.1930.

Diagnostic characters. Pseudocyphellae on the upper cortex are usually small and raised, sometimes associated with large ones (similar to those in C. chicitae) and small, but not raised (as in C. cetrarioides). Older thalli or only their central parts may lack pseudocyphellae. Soralia are often coarse and irregular in shape with soredia usually exceeding $40 \mu \mathrm{m}$ in diam. The lower cortex often lacks pseudocyphellae. Chemically C. monachorum is characterised by the producing of atranorin, imbricaric, 4-O-demethylimbricaric and anziaic acids. Perlatolic acid always occurs in minor amounts.

Notes. Cetrelia monachorum is morphologically and chemically very similar to $C$. cetrarioides and it was considered as its chemical race for a long time. Both taxa can be readily distinguished by the content of secondary metabolites, since $C$. monachorum contains imbricaric acid as the major medullary me- tabolite, whereas C. cetrarioides produces perlatolic acid.

Habitat requirements. Cetrelia monachorum was found in 26 habitats, of which 23 forest sites (Quercetum oxalidosum - 9 sites, Piceetum oxalidosum - 5, Glutinoso-alnetum urticosum - 4, Carpinetum oxalidosum - 3, Piceetum polytrichosum - 3, Glutinoso-alnetum caricosum - 2), transitional zone between alder swamp forest and ash forest and a roadside. The species was collected from Alnus glutinosa (14 specimens), Carpinus betulus (10), Quercus robur (4), Q. petraea (4), Fraxinus excelsior (2), Salix sp. (2), Populus tremula (1), Juniperus communis (1). Six of listed specimens were found on moss-covered trunks of Alnus glutinosa (3), Acer platanoides (1), Picea abies (1) and Quercus robur (1). In Poland, in the Białowieża Forest Cetrelia monachorum was collected from Carpinus betulus (1 specimen) and Populus tremula (1) (KuKwa et al. 2012).

Distribution in the Białowieża Forest. Cetrelia monachorum has been collected from 46 localities. The species is rather widely distributed in the Białowieża Forest but concentrated mainly on the territories which designated as a Strict Nature Reserve and World Heritage area (Fig. 3).

General distribution. In Europe it is know from Spain (BARBERo et al. 1995), Ukraine (KoNDrATYUK et al. 2003), Austria, Czech Republic, Germany, France, Italy, Norway, Romania, Slovakia, Slovenia, Switzerland (OBermayer \& Mayrhofer 2007), Montenegro (Obermayer \& Mayrhofer 2007, Knezevic \& MaYRHOFer 2009), Bosnia-Herzegovina (Bilovitz \& MAYRHOFer 2011), Poland (Kukwa et al. 2012), Lithuania (Kukwa \& Motiejūnaite 2012).

Outside Europe it has been recorded from China (Wei 1991), Hawaiian Islands (Elix \& McCARTHY 1998), Japan (KuroKaWA 2003), Armenia, Azerbaijan Republic (Sohrabi \& Alstrup 2007), Georgia (OberMAYer \& Mayrhofer 2007, Sohrabi \& Alstrup 2007), USA (Obermayer \& Mayrhofer 2007, Esslinger 2012), Asiatic part of Russia (URbanavichus \& ANDREEV 2010).

Specimens examined. Brest region, Kamenets district: Korolevo-Mostovskoe forest area, forest section No $740,52^{\circ} 36^{\prime} \mathrm{N} / 23^{\circ} 46^{\prime} \mathrm{E}$, Piceetum oxalidosum, on twigs of Quercus robur, P. Bely, 17.10.2009, 2020 MSKH; Korolevo-Mostovskoe forest area, forest section No 773, 52 $36^{\prime} \mathrm{N} / 23^{\circ} 48^{\prime} \mathrm{E}$, Quercetum oxalidosum, on trunk of Carpinus betulus, N. Gorbach, 14.05.1955, 7544 MSK; Korolevo-Mostovskoe forest area, forest section No $773,52^{\circ} 36^{\prime} \mathrm{N} / 23^{\circ} 48^{\prime} \mathrm{E}$, Glutinoso-alnetum caricosum, on Alnus glutinosa, P. Bely, 17.10.2009, $4630 \mathrm{MSKH}$; Pashuki forest area, section No 828, $52^{\circ} 34^{\prime} \mathrm{N} / 23^{\circ} 51^{\prime} \mathrm{E}$, on trunk of Salix sp. from roadside, 17.07.1983; Pashuki forest area, forest section No $827,52^{\circ} 34^{\prime} \mathrm{N} / 23^{\circ} 51^{\prime} \mathrm{E}$, Quercetum oxalidosum, on trunk of Quercus petraea, 17.07.1983; Pashuki forest area, forest section No 828, 52 $34^{\prime} \mathrm{N} / 23^{\circ} 51^{\prime} \mathrm{E}$, Quercetum oxalidosum, on trunk of Quercus petraea, 


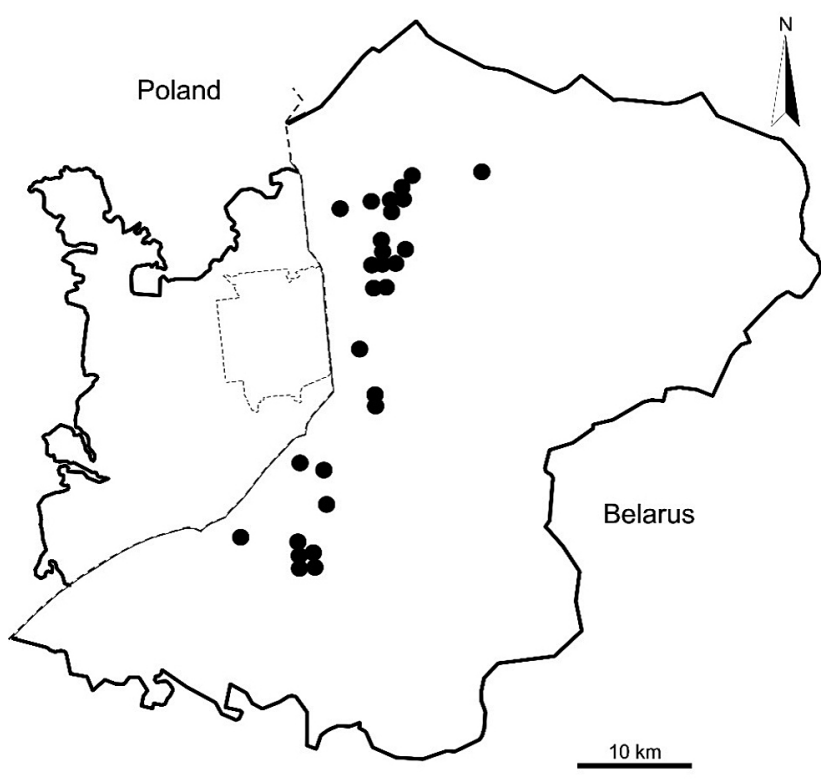

Fig. 3. Distribution of Cetrelia monachorum in the Białowieża Forest

17.07.1983; Korolevo-Mostovskoe forest area, forest section No $806,52^{\circ} 35^{\prime} \mathrm{N} / 23^{\circ} 52^{\prime} \mathrm{E}$, Quercetum oxalidosum, on trunk of Populus tremula, 12.07.1983; Pashuki forest area, forest section No $829,52^{\circ} 34^{\prime} \mathrm{N} / 23^{\circ} 53^{\prime} \mathrm{E}$, Quercetum oxalidosum, on trunk of Quercus petraea, 17.07.1983. Pruzhany district: Khvoiniki forest area, forest section No 459, 52 $41^{\circ} \mathrm{N} / 23^{\circ} 59^{\prime} \mathrm{E}$, Quercetum subalveto-fluviatilis, on trunk of the Alnus glutinosa at the road, 14.07.1984; Khvoiniki forest area, forest section No $434,52^{\circ} 42^{\prime} \mathrm{N} / 23^{\circ} 59^{\prime} \mathrm{E}$, Piceetum polytrichosum, on trunk of Quercus robur (at a height of 15 meters), 14.07.1984; Khvoiniki forest area, forest area No $434,52^{\circ} 42^{\prime} \mathrm{N} / 23^{\circ} 59^{\prime} \mathrm{E}$, Piceetum polytrichosum, on trunk of Carpinus betulus (at a height of 7 meters), 13.07.1984; Khvoiniki forest area, forest section No $434,52^{\circ} 42^{\prime} \mathrm{N} / 23^{\circ} 59^{\prime} \mathrm{E}$, Piceetum polytrichosum, on trunk of Carpinus betulus, 13.07.1984; Khvoiniki forest area, forest section No $434,52^{\circ} 42^{\prime} \mathrm{N} / 23^{\circ} 59^{\prime} \mathrm{E}$, Piceetum oxalidosum, on trunk of Alnus glutinosa, 13.07.1984; Khvoiniki forest area, forest section No 434, Piceetum oxalidosum, on a mossy trunk of $\mathrm{Al}$ nus glutinosa at a ditch, 13.07.1984; Khvoiniki forest area, forest section No $324,52^{\circ} 44^{\prime} \mathrm{N} / 23^{\circ} 59^{\prime} \mathrm{E}$, Quercetum oxalidosum, on branches of Carpinus betulus, 14.07.1984; Nikorskoe forest area, forest section No 589B, $52^{\circ} 38^{\prime} \mathrm{N} / 23^{\circ} 55^{\prime} \mathrm{E}$, Quercetum oxalidosum, on trunk of Carpinus betulus, 14.07.1983; Nikorskoe forest area, forest section No $589,52^{\circ} 38^{\prime} \mathrm{N} / 23^{\circ} 55^{\prime} \mathrm{E}$, Quercetum filicosum, on trunk of Quercus robur, 13.06.1984; forest section No $589,52^{\circ} 38^{\prime} \mathrm{N} / 23^{\circ} 55^{\prime} \mathrm{E}$, Quercetum oxalidosum, on the trunk of the Alnus glutinosa covered with a moss, 22.06.1984; Nikorskoe forest area, forest section No $589,52^{\circ} 38^{\prime} \mathrm{N} / 23^{\circ} 55^{\prime} \mathrm{E}$, Piceetum filicosum, on trunk of Quercus petraea, 15.07.1984; Korolevo-Mostovskoe forest area, forest section No 554, 52 $39^{\prime} \mathrm{N} / 23^{\circ} 52^{\prime} \mathrm{E}$, Piceetum oxalidosum, on the trunk of the Fraxinus excelsior, 22.06.1984; Nikorskoe forest area, forest section No $682,683,52^{\circ} 37^{\prime} \mathrm{N} / 23^{\circ} 54^{\prime} \mathrm{E}$, Glutinoso-alnetum urticosum, on Acer platanoides, 10.06.1983. Grodno region, Svisloch district: Brovsk forest area, forest section No $103,52^{\circ} 51^{\prime} \mathrm{N} / 24^{\circ} 00^{\prime} \mathrm{E}$, Pinetum myrtillosum, on Juniperus communis, 25.09.1984; Brovsk forest area, forest section No $74,52^{\circ} 52^{\prime} \mathrm{N} / 24^{\circ} 02^{\prime} \mathrm{E}$, transitional zone of alder swamp forest in ash forest, on the trunk of the Alnus glutinosa, 20.07.1984; forest section No $72,52^{\circ} 50^{\prime} \mathrm{N} / 24^{\circ} 01^{\prime} \mathrm{E}$, Glutinoso-alnetum caricosum, on the trunk of the Alnus glutinosa, 21.07.1984; Brovsk forest area, forest section No $72 \mathrm{~B}, 52^{\circ} 49^{\prime} \mathrm{N} / 24^{\circ} 01^{\prime} \mathrm{E}$, Glutinoso-alnetum aegopodiosum, on the fallen trunk of the Fraxinus excelsior, 20.07.1984; Yazvinsky forest area, forest section No $172,52^{\circ} 48^{\prime} \mathrm{N} / 24^{\circ} 01^{\prime} 37^{\prime \prime} \mathrm{E}, B e-$ tuletum caricosum, on a mossy fallen trunk of the Alnus glutinosa, 20.08.1984; Yazvinsky forest area, forest section No $115 \mathrm{~A}, 52^{\circ} 49^{\prime} \mathrm{N} / 24^{\circ} 02^{\prime} \mathrm{E}$, Piceetum caricosum, on the trunk of the Alnus glutinosa, 5.07.1984; Yazvinsky forest area, forest section No 115A, $52^{\circ} 49^{\prime} \mathrm{N} / 24^{\circ} 02^{\prime} \mathrm{E}$, Piceetum caricosum, on a mossy trunk of the Picea abies, 5.07.1984; Novoselkovskoe forest area, forest section No $172,52^{\circ} 47^{\prime} \mathrm{N} / 24^{\circ} 00^{\prime} \mathrm{E}$, Pinetum caricosum, on mossy branches of Carpinus betulus (at a height of 15 meters), 23.07.1984; Novoselkovskoe forest area, forest section No 172 , $52^{\circ} 48^{\prime} \mathrm{N} / 24^{\circ} 01^{\prime} \mathrm{E}$, Pinetum caricosum, on the trunk of the Alnus glutinosa, 23.07.1984; Novoselkovskoe forest area, forest section No $114,52^{\circ} 49^{\prime} \mathrm{N} / 24^{\circ} 01^{\prime} \mathrm{E}$, Glutinoso-alnetum urticosum, on the trunk of the Acer platanoides, 21.07.1984; Brovsk forest area, forest section No $105,52^{\circ} 51^{\prime} \mathrm{N} / 24^{\circ} 02^{\prime} \mathrm{E}$, Carpinetum oxalidosum, on a mossy trunk of the fallen Acer platanoides, 28.09.1984; Svislochskoe forest area, forest area No $106,52^{\circ} 51^{\prime} \mathrm{N} / 24^{\circ} 03^{\prime} \mathrm{E}$, Carpinetum oxalidosum, on trunk of the old Carpinus betulus, 28.07.1984; Yazvinskoe forest area, forest section No 113, $52^{\circ} 48^{\prime} \mathrm{N} / 24^{\circ} 00^{\prime} \mathrm{E}$, Glutinoso-alnetum urticosum, on a mossy branch of Quercus robur, 28.07.1984; Brovsk forest area, forest section No $76,52^{\circ} 52^{\prime} \mathrm{N} / 24^{\circ} 04^{\prime} \mathrm{E}$, Piceetum oxalidosum, on trunk of Carpinus betulus, 28.07.1984; Brovsky forest area, forest section No $76 \mathrm{~A}, 52^{\circ} 52^{\prime} \mathrm{N} / 24^{\circ} 06^{\prime} \mathrm{E}$, Aceretum oxalidosum, on trunk of Carpinus betulus, 28.07.1984; Brovsky forest area, forest section No $76,52^{\circ} 52^{\prime} \mathrm{N} / 24^{\circ} 06^{\prime} \mathrm{E}$, Quercetum oxalidosum, on trunk of Carpinus betulus, 16.07.1984; Brovsk forest area, forest section No $89,52^{\circ} 49^{\prime} \mathrm{N} / 24^{\circ} 01^{\prime} \mathrm{E}$, Glutinoso-alnetum thelipteridosum, on trunk of Alnus glutinosa, 21.07.1984; Brovsky forest area, forest section No $91,52^{\circ} 51^{\prime} \mathrm{N} / 24^{\circ} 00^{\prime} \mathrm{E}$, Glutinoso-alnetum urticosum, on trunk of Salix sp. from roadside, 27.07.1984; Brovsk forest area, forest area No $106,52^{\circ} 51^{\prime} \mathrm{N} / 24^{\circ} 03^{\prime} \mathrm{E}$, Carpinetum oxalidosum, on trunk of the Alnus glutinosa, 28.07.1984; Brovsk forest area, forest section No $105,52^{\circ} 51^{\prime} \mathrm{N} / 24^{\circ} 02^{\prime} \mathrm{E}$, Glutinoso-alnetum oxalidosum, on the trunk of the Alnus glutinosa, 25.07.1984; Svislochskoe forest area, 
forest section No $82,52^{\circ} 52^{\prime} \mathrm{N} / 24^{\circ} 00^{\prime} \mathrm{E}$, Glutinoso-alnetum oxalidosum, on a trunk of Alnus glutinosa, 17.07.1984.

\section{CETRELIA OLIVETORUM (NYL.) W.L. CULB. \& C.F. CULB.}

Contrib. U.S. Natl. Herb. 34: 515.1968. = Parmelia olivetorum Nyl., Not. Sällsk. Fauna Fl. Fenn. Forh. 8: 180.1866

Diagnostic characters. Cetrelia olivetorum is characterised by its small, not raised pseudocyphellae on upper cortex, rare occurrence of pseudocyphellae on lower cortex, often smooth and convex soralia with farinose to coarse soredia, and production of olivetoric acid as the major secondary compound in medulla.

Notes. Cetrelia olivetorum can be easily distinguished from $C$. cetrarioides and C. monachorum by its very distinctly red reaction with $\mathrm{C}$ and the production of olivetoric acid. Besides, a reticulate lower surface is more frequently developed in C. olivetorum than in the other taxa.

Habitat requirements. Cetrelia olivetorum was collected in 31 localities, including 30 forest habitats (Glutinoso-alnetum caricosum - 8 samples, Quercetum oxalidosum - 6, Piceetum caricosum - 4, Piceetum oxalidosum - 2, Quercetum filicosum - 2, Glutinoso-alnetum oxalidosum - 2, Carpinetum oxalidosum - 2, Pinetum oxalidosum - 1) and a roadside. Cetrelia olivetorum was collected on Alnus glutinosa (8 specimens), Quercus robur (5), Fraxinus excelsior (4), Acer platanoides (2), Carpinus betulus (2), Populus tremula (2) and Quercus petraea (2). In Poland, in the Białowieża Forest Cetrelia olivetorum was collected from Quercus sp. (1 specimen) and Carpinus betulus (4) (KuKwA et al. 2012).

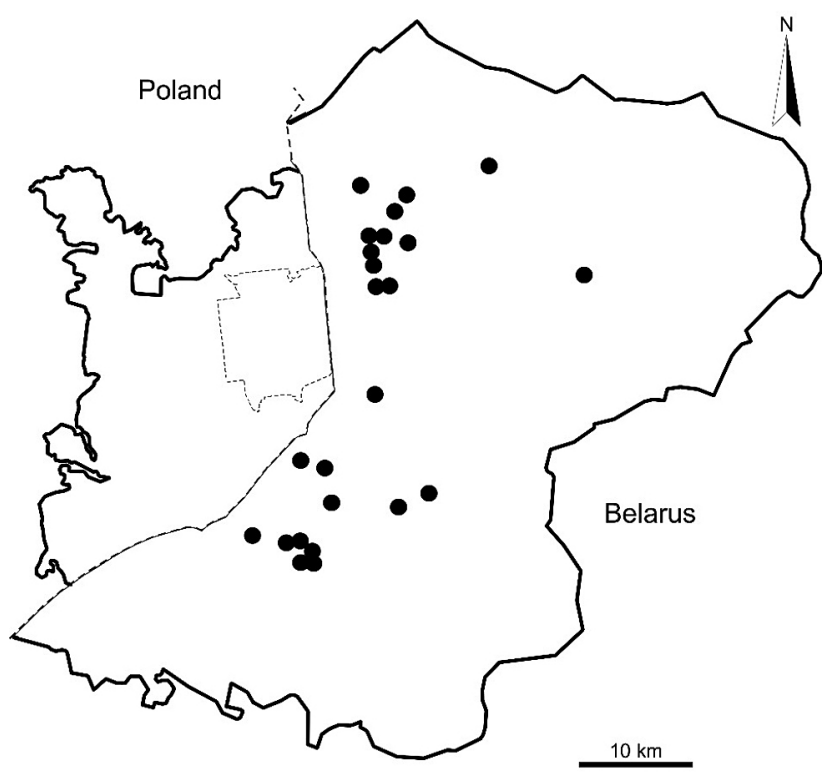

Fig. 4. Distribution of Cetrelia olivetorum in the Białowieża Forest
Distribution in the Białowieża Forest. Distribution of the species is similar to C. monachorum. Cetrelia olivetorum was collected from 35 localities (Fig. 4).

General distribution. The species has been reported in Europe from Ireland (SEAWARD 1994), Portugal (Azores), Spain (BARBERo et al. 1995), Great Britain (Coppins 2002), Italy (Nimis \& Martellos 2002), Latvia (PIterans 2002), Finland, Sweden (SANTESSON et al. 2004), Ukraine (KondRATYuK et al. 2003), Lithuania (Motiejũnaite et al. 2004), Estonia (Randlane et al. 2006), Serbia (SAvic \& Tibell 2006), Austria, Czech Republic, Germany, Hungary, Portugal (Madeira), Romania, Slovenia (Obermayer \& MAYrhofer 2007), Montenegro (KNezevic \& Mayrhofer 2009), Russia (Urbanavichus \& Andreev 2010), Bosnia-Herzegovina (Bilovitz \& MAYrhofer 2011), Poland (KuKwa et al. 2012), Lithuania (Kukwa \& Motiejũnaite 2012).

It has also been reported from China (WeI 1991), Papua New Guinea (AртRоoт et al. 1997), Bhutan (Aptroot \& Feijen 2002), Thailand (Wolseley et al. 2002), Turkey (YAZÝCÝ \& AsLAN 2002), Taiwan (APTROot et al. 2003), Japan (Kurokawa 2003), Armenia, Azerbaijan Republic (Sohrabi \& Alstrup 2007), Canada, Georgia (Obermayer \& Mayrhofer 2007), USA (OBermayer \& MAYrhofer 2007, Esslinger 2012), Asiatic part of Russia (URBANAvichus \& ANDREev 2010), India (Sikkim) (SINGH \& SinHA 2010).

Specimens examined. Brest region, Kamenets district: Korolevo-Mostovskoe forest area, forest section No $777,52^{\circ} 35^{\prime} \mathrm{N} / 23^{\circ} 51^{\prime} \mathrm{E}$, Quercetum oxalidosum, on trunk of the Quercus petraea, 18.07.1983; Korolevo-Mostovskoe forest area, forest section No 807, $52^{\circ} 35^{\prime} \mathrm{N} / 23^{\circ} 52^{\prime} \mathrm{E}$, Quercetum oxalidosum, on trunk of Quercus robur, 11.07.1983; Pashuki forest area, forest section No $828,52^{\circ} 34^{\prime} \mathrm{N} / 23^{\circ} 51^{\prime} \mathrm{E}$, Quercetum oxalidosum, on trunk of Salix sp., 17.07.1983; Pashuki forest area, forest section No $829,52^{\circ} 34^{\prime} \mathrm{N} / 23^{\circ} 53^{\prime} \mathrm{E}$, Quercetum oxalidosum, on trunk of Quercus robur, 11.07.1983; Pashuki forest area, forest section No $829,52^{\circ} 34^{\prime} \mathrm{N} / 23^{\circ} 53^{\prime} \mathrm{E}$, Quercetum oxalidosum, on trunk of the Quercus petraea, 17.07.1983; Pruzhany district: Khvoinik forest area, forest section No 434B, 52 $42^{\prime} \mathrm{N} / 23^{\circ} 59^{\prime} \mathrm{E}$, Quercetum oxalidosum, on the trunk of the Quercus robur, 13.07.1984; Korolevo-Mostovskoe forest area, forest section No 554, $52^{\circ} 39^{\prime} \mathrm{N} / 23^{\circ} 52^{\prime} \mathrm{E}$, Piceetum fontinale-herbosum, on mossy trunk of Fraxinus excelsior, 20.07.1984; Nikorskoe forest area, forest section No 589, $52^{\circ} 38^{\prime} \mathrm{N} / 23^{\circ} 55^{\prime} \mathrm{E}, \quad$ Glutinoso-alnetum thelipteriosum, on the trunk of the Alnus glutinosa, 15.07.1984; Pererovskoe forest area, forest section No 589, $52^{\circ} 38^{\prime} \mathrm{N} / 23^{\circ} 55^{\prime} \mathrm{E}$, Quercetum filicosum, on the trunk of the Quercus robur, 16.07.1984; Nikorskoe forest area, forest section No $683,52^{\circ} 57^{\prime} \mathrm{N} / 23^{\circ} 55^{\prime} \mathrm{E}$, Glutinoso-alnetum oxalidosum, on trunk of Salix sp. from roadside, 17.07.1983; Nikorskoe forest area, forest section No $683,52^{\circ} 57^{\prime} \mathrm{N} / 23^{\circ} 55^{\prime} \mathrm{E}$, Carpinetum oxalidosum, on the 
trunk Acer platanoides, 10.06.1983; Nikorskoe forest area, forest section No $683,52^{\circ} 57^{\prime} \mathrm{N} / 23^{\circ} 55^{\prime} \mathrm{E}$, Carpinetum oxalidosum, on Carpinus betulus, 10.06.1983; Nikorskoe forest area, forest section No 720, $52^{\circ} 36^{\prime} \mathrm{N} / 24^{\circ} 00^{\prime} \mathrm{E}$, Pinetum oxalidosum, on a mossy trunk of Fraxinus excelsior, 8.07.1984; Grodno region. Svisloch district: Brovsk forest area, forest section No $87,52^{\circ} 51^{\prime} \mathrm{N} / 24^{\circ} 00^{\prime} \mathrm{E}$, Glutinoso-alnetum caricosum, on trunk of old Alnus glutinosa, 25.09.1984; Yazvinskoe forest area, forest section No $72,52^{\circ} 49^{\prime} \mathrm{N} / 24^{\circ} 00^{\prime} \mathrm{E}$, Glutinoso-alnetum caricosum, on a mossy trunk of the Fraxinus excelsior, 20.07.1984; Yazvinskoe forest area, forest section No $72,52^{\circ} 49^{\prime} \mathrm{N} / 24^{\circ} 00^{\prime} \mathrm{E}$, Glutinoso-alnetum caricosum, on trunk of Salix sp. from roadside, 27.07.1984; Yazvinskoe forest area, forest section No $91,52^{\circ} 50^{\prime} \mathrm{N} / 24^{\circ} 04^{\prime} \mathrm{E}$, Piceetum oxalidosum, on trunk bases of Populus tremula, 27.07.1984; Brovsk forest area, forest section No $120,52^{\circ} 50^{\prime} \mathrm{N} / 24^{\circ} 02^{\prime} \mathrm{E}$, Glutinoso-alnetum caricosum, on the fallen fragments covered with a moss, 26.07.1984; Brovsk forest area, forest section No $120,52^{\circ} 50^{\prime} \mathrm{N} / 24^{\circ} 02^{\prime} \mathrm{E}$, Glutinoso-alnetum caricosum, on trunk of the inclined birch, 26.07.1984; Brovsk forest area, forest section No $104,52^{\circ} 51^{\prime} \mathrm{N} / 24^{\circ} 03^{\prime} \mathrm{E}$, Glutinoso-alnetum caricosum, on trunk of Alnus glutinosa in open situations, 26.07.1984; Brovsk forest area, forest section No 105, $52^{\circ} 51^{\prime} \mathrm{N} / 24^{\circ} 03^{\prime} \mathrm{E}$, Carpinetum myrtillosum, on a trunk of fallen Acer platanoides, 27.07.1984; Svislochskoe forest area, forest section No $106,52^{\circ} 51^{\prime} \mathrm{N} / 24^{\circ} 03^{\prime} \mathrm{E}$, Aceretum oxalidosum, on trunk of old Alnus glutinosa, 28.09.1984; Yazvinskoe forest area, forest section No $113,52^{\circ} 48^{\prime} \mathrm{N} / 24^{\circ} 00^{\prime} \mathrm{E}$, Glutinoso-alnetum caricosum, on the branches of the Quercus robur (at a height of 15 meters), 23.07.1984; Yazvinskoe forest area, forest section No $91,52^{\circ} 49^{\prime} \mathrm{N} / 24^{\circ} 03^{\prime} \mathrm{E}$, Quercetum filicosum, on trunk of Salix sp., 26.07.1984; Yazvinskoe forest area, forest section No $88,52^{\circ} 49^{\prime} \mathrm{N} / 24^{\circ} 00^{\prime} \mathrm{E}$,
Glutinoso-alnetum caricosum, on windfall of Alnus glutinosa, 25.07.1984; Yazvinskoe forest area, forest section No $114,52^{\circ} 49^{\prime} \mathrm{N} / 24^{\circ} 02^{\prime} \mathrm{E}$, Glutinoso-alnetum oxalidosum, on trunk of Fraxinus excelsior, 21.07.1984; Yazvinskoe forest area, forest section No 172, $52^{\circ} 47^{\prime} \mathrm{N} / 24^{\circ} 01^{\prime} \mathrm{E}$, Piceetum caricosum, on trunk Alnus glutinosa, 27.07.1984; Yazvinskoe forest area, forest section No $172,52^{\circ} 47^{\prime} \mathrm{N} / 24^{\circ} 01^{\prime} \mathrm{E}$, Piceetum caricosum, on trunk of Alnus glutinosa, 18.07.1984; Yazvinskoe forest area, forest section No $172,52^{\circ} 47^{\prime} \mathrm{N} / 24^{\circ} 01^{\prime} \mathrm{E}$, Piceetum caricosum, on a mossy trunk of the fallen $\mathrm{Al}$ nus glutinosa, 18.07.1984; Yazvinskoe forest area, forest section No $171 / 172,52^{\circ} 47^{\prime} \mathrm{N} / 24^{\circ} 01^{\prime} \mathrm{E}$, Piceetum caricosum, on branch of windfall of Carpinus betulus, 23.07.1984; Novoselkovskoe forest area, forest section No $204,52^{\circ} 47^{\prime} \mathrm{N} / 24^{\circ} 17^{\prime} \mathrm{E}$, Piceetum oxalidosum, on branch of Populus tremula, A. Yatsyna, 14.08.2011, 8010 MSK.

Occurrence of lichens of the genus Cetrelia on the bark of different species of trees in the Białowieża Forest (Belarus) shows Figure 5.

In the Belarusian part of the Białowieża Forest Cetrelia species are the typical epiphytes and usually grow on deciduous trees. In general, Fraxinus excelsior, Carpinus betulus and Quercus robur are the most common substrates for Cetrelia species of the investigated area.

Table 2 summarizes the lichen substances found. The genus Cetrelia W.L. Culb. \& C.F. Culb. is characterised by atranorin as the main cortical secondary metabolite (only C. cetrarioides, C. monachorum); the species produce several depsidones as diagnostic medullary substances.

Table 3 summarizes the morphology of the lichen thallus of the genus Cetrelia in the Białowieża Forest (Belarussian part). The thallus was found to be foliose, loosely attached grey thallus with laminal pseu-

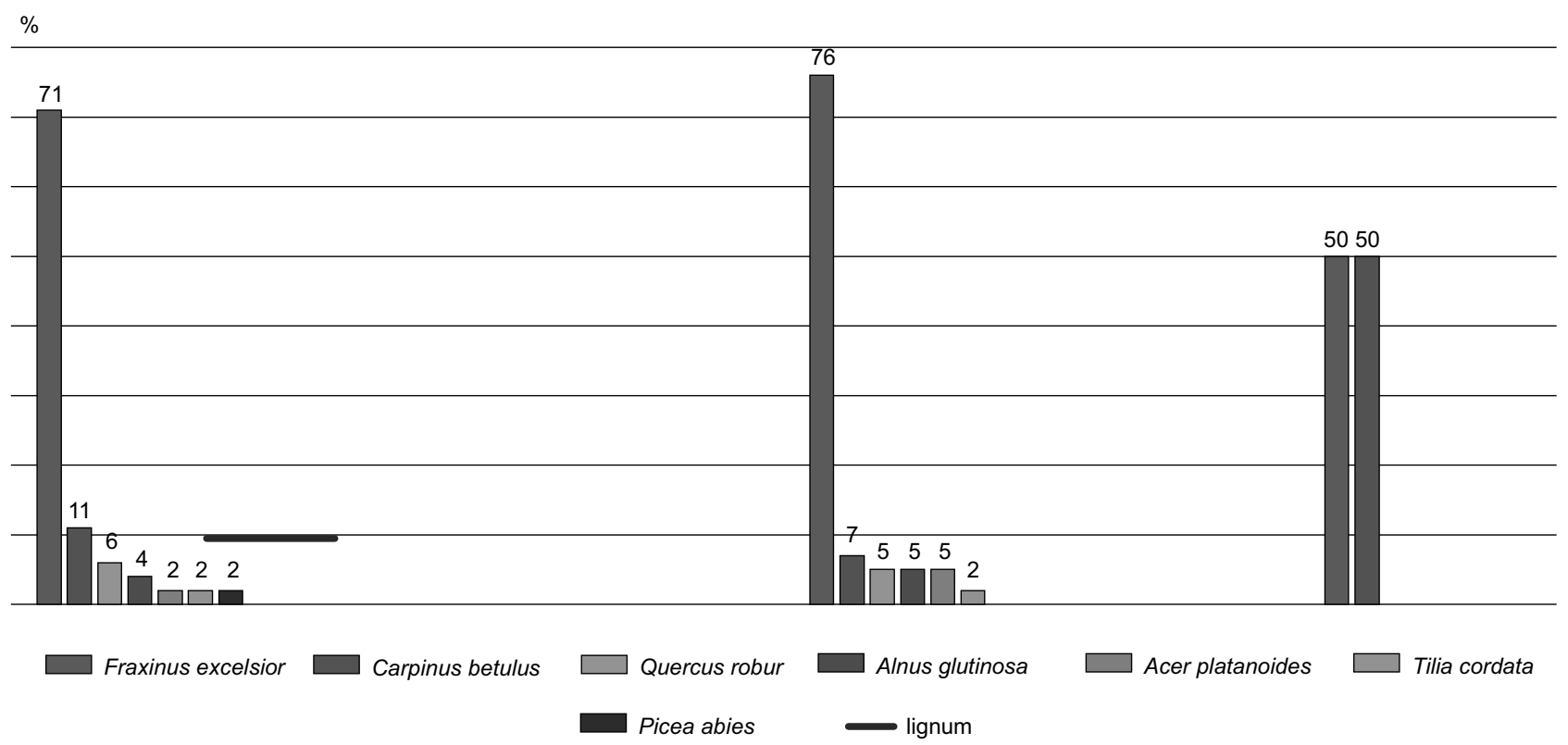

Fig. 5. Substrate preference of Cetrelia cetraroides, C. monachorum and C. olivetorum in the Białowieża Forest (Belarus) 
Table 2. Summary of the major lichen substances in lichen thalli of the genus Cetrelia in the Białowieża Forest found

\begin{tabular}{|c|c|c|c|c|c|c|}
\hline \multirow[b]{2}{*}{ Lichen substances } & \multicolumn{2}{|c|}{ Cetrelia cetrarioides } & \multicolumn{2}{|c|}{ Cetrelia monachorum } & \multicolumn{2}{|c|}{ Cetrelia olivetorum } \\
\hline & $\begin{array}{c}\text { Poland } \\
\text { (KuKWA } \\
\text { et al. 2012) }\end{array}$ & $\begin{array}{c}\text { Belarus, } \\
\text { Białowieża } \\
\text { Forest }\end{array}$ & $\begin{array}{c}\text { Poland } \\
\text { (KuKwA } \\
\text { et al. 2012) }\end{array}$ & $\begin{array}{c}\text { Belarus, } \\
\text { Białowieża } \\
\text { Forest }\end{array}$ & $\begin{array}{c}\text { Poland } \\
\text { (KuKWA } \\
\text { et al. 2012) }\end{array}$ & $\begin{array}{c}\text { Belarus, } \\
\text { Białowieża } \\
\text { Forest }\end{array}$ \\
\hline $\begin{array}{l}\text { Atranorin } \\
\text { Alectotonic acid }\end{array}$ & + & + & + & + & & \\
\hline $\begin{array}{l}\text { Anziaic acid } \\
\alpha \text {-collatolicacid }\end{array}$ & + & + & \pm & + & & \\
\hline Imbricaric acid & & \pm & + & + & & \\
\hline Olivetoric acid & & & & & + & + \\
\hline 4-O-methylolivetoric acid & + & + & & & & \\
\hline Perlatolic acid & + & + & + & \pm & & \\
\hline 4-O-demethylimbricaric acid & & & \pm & + & & \\
\hline 4-O-methylphysodic acid & & & & & & \\
\hline Physodic acid & & & & & & \\
\hline
\end{tabular}

Explanation: + always present, \pm occasionally present.

Table 3. Summary of the characteristic morphology of pseudocyphelle, soralia and soredia of the Białowieża species of Cetrelia in the Białowieża Forest (Belarussian part)

\begin{tabular}{|c|c|c|c|}
\hline Species/Morphology & Cetrelia cetrarioides & Cetrelia monachorum & Cetrelia olivetorum \\
\hline Pseudocyphellae & $\begin{array}{l}\text { on the upper surface small to rath- } \\
\text { er large, almost always not raised, } \\
\text { and those on the lower surface of } \\
\text { the lobes well developed }\end{array}$ & $\begin{array}{l}\text { on the upper cortex are usually } \\
\text { small and raised, sometimes } \\
\text { associated with large ones (similar } \\
\text { to those in C. chicitae) and small, } \\
\text { but not raised (as in C. cetrarioides) }\end{array}$ & $\begin{array}{l}\text { on upper cortex, rare occurrence } \\
\text { of pseudocyphellae on lower } \\
\text { cortex small, not raised pseudo- } \\
\text { cyphellae }\end{array}$ \\
\hline Soralia & smooth and very convex & often coarse and irregular in shape & smooth and convex soralia \\
\hline Soredia & $\begin{array}{l}\text { small (usually up to } 35 \mu \mathrm{m} \text { in } \\
\text { diam.) }\end{array}$ & usually exceeding $40 \mu \mathrm{m}$ in diam. & $\begin{array}{l}\text { farinose to coarse soredia }(25-55 \\
\mu \mathrm{m} \text { in diam.) }\end{array}$ \\
\hline
\end{tabular}

docyphellae, prosoplectenchymatous upper cortex, at least partly black lower cortex with sparse rhizines, marginal pycnidia. These characters separate Cetrelia from other morphologically similar genera such as Parmotrema A. Massal. and Platismatia W.L. Culb. \& C.F. Culb. (Culberson \& Culberson 1968).

In the Belarussian part of the Białowieża Forest Cetrelia olivetorum and C. monachorum are the commonest member of the genus, whereas $C$. cetrarioides is known only from two records. The current version of the Red Data Book of Belarus lists only Cetrelia cetrarioides s.l. as a vulnerable (VU) species (KHORUZHIK et al. 2005). Our revision has shown that of the three recorded Cetrelia species, C. cetrarioides is the least frequent one in the Białowieża Forest as well as in Belarus in general (BELY et al. 2014).

\section{ACKNOWLEDGEMENTS}

The paper has been financially supported by the Polish Ministry of Science and Higher Education through statutory research.

\section{REFERENCES}

Aptroot A., Diederich P., Serusiaux E., Sipman H.J.M. (1997): Lichens and lichenicolous fungi from New Guinea. Bibliotheca Lichenologica 64: 1-2.
Aptroot A., Feijen F.J. (2002): Annotated checklist of the lichens and lichenicolous fungi of Bhutan. Fungal Diversity 11: 21-48.

Aptroot A., Ferraro L.I., Lai M.-L., Sipman H.J.M., SPARrIUS L.B. (2003): Foliicolous lichens and their lichenicolous Ascomycetes from Yunnan and Taiwan. Mycotaxon 88: 41-47.

Barbero M., Etayo J., Gómez-Bolea A. (1995): Chemotypes of Cetrelia cetrarioides s.l. (Lichenes) in the Iberian Peninsula. Cryptogamic Botany 5(1): 28-30.

Bely P.N. (2011): Annotirovannyi spisok lishainikov i likhenofilnykh gribov elovykh ekosistem Belarusi [Annotated list of lichens and lichenicolous fungi of spruce forests of Belarus]. Osobo ohranyaemye prirodnye territorii Belarusi (issledovaniуa) 6: 146-178.

Bely P., Golubkov V., Tsurykau A., Sidorovich E. (2014): The lichen genus Cetrelia in Belarus: distribution, ecology and conservation. Botanica Lithuanica 20(2): 69-76.

Bilovitz P.O., Mayrhofer H. (2011): Epiphytic lichen mycota of the virgin forest reserve Rajhenavski Rog (Slovenia). Herzogia 24(2): 315-324.

Coppins B.J. (2002): Checklist of lichens of Great Britain and Ireland. British Lichen Society, Huddersfield.

Culberson C.F., Culberson W.L. (1976): Chemosyndromic variation in lichens. Systematic Botany 1: 325-339. 
Culberson C.F., Kristinsson H. (1970): A standardized method for the identification of lichen products. Journal of Chromatography 46: 85-93.

Culberson W.L., Culberson C.F. (1968): The lichen genera Cetrelia and Platismatia (Parmeliaceae). Contributions from the United States National Herbarium 34(7): 449-558.

Decisions adopted by the World Heritage Committee at its 38th session (2014). Doha, Qatar.

Elix J.A., Mc Carthy P.M. (1998): Catalogue of the lichens of the smaller Pacific Islands. Bibliotheca Lichenologica 70: 1-361.

EsSLINGER T.L. (2012): A cumulative checklist for the lichen-forming, lichenicolous and allied fungi of the continental United States and Canada. North Dakota State University: http://www.ndsu.edu/ pubweb/ esslinge/chcklst/chcklst7.htm [access: 20.05.2014].

Feuerer T. (2010): Checklists of lichens and lichenicolous fungi [Internet]. 2010 [cited 2013 Aug 18]; Available from: http://www.checklists.de.

GolubKov V. (1986): The eco-geografic characteristic of some rare and relic species of the lichens growing on the protected natural territories Belarusian the Soviet Socialist Republic. Botany 27: 139-141.

GolubKov V.V. (1987): Species composition and structure of the lichen flora of the State hunting reserve "Białowieża Forest». Part 1. The species composition of lichen flora of the Białowieża Forest (annotated list). Belarusian Academy of Sciences, Minsk.

Golubkov V. (2011): Lichen biota of Prypyatskij National Park. Belarusian Printing House, Minsk.

Gorbach N.V. (1973): Lishajniki Belorussii. Nauka i Tekhnika, Minsk.

Hawksworth D.L., Blanco O., Divakar P.K., Ahti T., Crespo A. (2008): A first checklist of parmelioid and similar lichens in Europe and some adjacent territories, adopting revised generic circumscriptions and with indications of species distributions. The Lichenologist 40: 1-21.

Hawksworth D.L., Divakar P.K., Crespo A., Ahti T. (2011): The checklist of parmelioid and similar lichens in Europe and some adjacent territories: additions and corrections. The Lichenologist 43: 639-645.

Khoruzhik L.I., Suschenya L.M., Parfenov V.I. (eds) (2005): Krasnaja kniga Respubliki Belarus: redkie i nachodjaščiesja pod ugrozoj isčeznovenija vidy dikorastuščich rastenij. Belen, Minsk.

Knezevic B., Mayrhofer H. (2009): Catalogue of the lichenized and lichenicolous fungi of Montenegro. Phyton 48, 2: 283-328.

Kondratyuk S.YA., Popoval P., Lackovičová A., Pišút J. (2003): A catalogue of eastern Carpathians lichens. M.H. Kholodny Institute of Botany, Kiev-Bratislava.
Kravchuk V. (2015): Biosphere Reserve «Belovezhskaya Pushcha» has found a modern territorial structure [Internet]. 2015 [cited 2015 June 1]; available from: http://http://npbp.brest.by/ новости/305-биосферный-резерват-«беловежскаяпуща»-обрел-границы.

Kukwa M., Motiejũnaite J. (2012): Revision of the genera Cetrelia and Punctelia (Lecanorales, Ascomycota) in Lithuania, with implications for their conservation. Herzogia 25(1): 5-14.

Kukwa M., Pietnoczko M., Czyżewska K. (2012): The lichen family Parmeliaceae in Poland. 2. The genus Cetrelia. Acta Societatis Botanicorum Poloniae 81(1): 43-52.

KurokawA S. (ed.) (2003): Checklist of Japanese lichens. National Science Museum, Tokyo.

Lai M.J., Chen X.L., Qian Z.G., Xu L., Ahti T. (2009): Cetrarioid lichen genera and species in NE China. Annales Botanici Fennici 46: 365-380.

Motiejũnaite J., Czyżewska K., Cieśliński S. (2004): Lichens - Indicators of old-growth forests in biocentres of Lithuania and north-east Poland. Botanica Lithuanica 10, 1: 59-74.

Nimis P.L., Martellos S. (2002): Italic, a database on Italian Lichens. Bibliotheca Lichenologica 82: 271-282.

Obermayer W., Mayrhofer H. (2007): Hunting for Cetrelia chicitae (lichenized Ascomycetes) in the eastern European Alps (including an attempt for a morphological characterization of all taxa of the genus Cetrelia in Central Europe). Phyton 47: 231-290.

Orange A., James P.W., White F.J. (2001): Microchemical methods for the identification of lichens. British Lichen Society, London.

Otnyukova T.N., Stepanov N.V., Elix J.A. (2009): Three new species of Parmeliaceae (Ascomycota) from Siberia. Mycotaxon 108(1): 249-256.

Piterans A. (2002): Lichens of Latvia. http://latvijas. daba.lv/scripts/db/saraksti/saraksti.cgi?d=keerpji\&l=en.

Randlane T., SAag A. (1991): Chemical and morphological variation in the genus Cetrelia in the Soviet Union. The Lichenologist 23: 113-126.

Randlane T., SAag A. (2004): Distribution patterns of some primary and secondary cetrarioid species. Acta University Uppsala Acta Universitatis Upsaliensis Symbolae Botanicae Upsaliense 34: 359-376.

Randlane T., Saag A., Suija A. (2006): Lichenized, lichenicolous and allied fungi of Estonia [Internet]. 2006 [cited 2010 Aug. 18]; Available from: http://www.ut.ee/lichens/fce.html.

Santesson R., Moberg R., Nordin A., Tønsberg T., VitiKAINEN O. (2004): Lichen-forming and lichenicolous fungi of Fennoscandia. Uppsala Museum of Evolution, Uppsala University, Uppsala. 
Savic S., Tibell L. (2006): Checklist of the lichens of Serbia. Mycologia Balcanica 3: 187-215.

SEAWARD M.R.D. (1994): Vice-county distribution of Irish lichens. Biology Environment 94b: 177-194.

SingH K.P., SinHA G.P. (2010): Indian lichens: An annotated checklist. Ministry Environment Forests, Salt Lake City.

Sohrabi M., Alstrup V. (2007): Additions to the lichen mycota of Iran from East Azerbaijan Province. Mycotaxon 100: 145-148.

Tsurykau A.G. (2013): Lichens of southeastern Belarus (experience of lichen monitoring). Gomel State University named by F. Skorina, Gomel.

Urbanavichus G., Andreev M. (2010): A checklist of lichen flora of Russia. Nauka, St. Petersburg.

WeI J.-C. (1991): An enumeration of lichens in China. International Academic Publishers, Beijing.
Wolseley P.A., Aguirre-Hudson B., Mc Carthy P. (2002): Catalogue of the lichens of Thailand. Bulletin of the Natural History Museum (Botany) 32, 1: 13-59.

YazÝCÝ K., Aslan A. (2002): Additional lichen records from Rize Province. Turkish Journal of Botany 26: 181-193.

YuRKevich I.D., Lovchi N.F., Geltman V.S. (1977): The forests of Byelorussian Polessia (Geobotanical investigations). Nauka i Tekhnika, Minsk.

For citation: Golubkov V., Matwiejuk A., Bely P., Tsurykau A. (2015): Revision of the genus Cetrelia (Lecanorales, Ascomycota) in the Białowieża Forest (Belarussian part). Steciana 19(3): 123-132. doi:10.12657/steciana.019.014 